\title{
LAYERS AND PROCESSES IN THE MODEL OF TECHNOLOGICAL POSTAL SYSTEM
}

\author{
Lucia Madleňáková ${ }^{1}$, Radovan Madleňák ${ }^{2}$, Paweł Droździel ${ }^{3}$, Ivan Kurtev ${ }^{4}$ \\ ${ }^{1}$ University of Žilina \\ Žilina, Slovakia, Univerzitná 1 \\ Ph.: +421 41513 3125, e-mail: lucia.madlenakova@fpedas.uniza.sk \\ ${ }^{2}$ University of Žilina \\ Žilina, Slovakia, Univerzitná 1 \\ Ph.: +421 41513 3124, e-mail: radovan.madlenak@fpedas.uniza.sk \\ ${ }^{3}$ Lublin University of Technology \\ Lublin, Poland, Nadbystrzycka 38 \\ Ph.: +48815384190, e-mail: p.drozdziel@pollub.pl \\ ${ }^{4}$ Technical university of Sofia \\ Sofia, Bulgaria, $8 \mathrm{Kl}$. Ohridski Blvd \\ Ph.: +359887393188,e-mail:i.kurtev@mail.bg
}

\begin{abstract}
The paper include important aspects of layer model of postal technological system such as makes the possibility to define rules for regulating, technical and technological requirements and interfaces to communicate with other postal systems. The current postal reform is mainly attributable to release of network access and ensuring full interoperability between technological systems. Not only to ensure the development and protection of competition but also in respect to the conservation of requirements to provide the universal service, which is the performance of public interest. There is a space here to examine the postal system, not only from a procedural point of view, but to be viewed as an open communication system. It is possible to find there the commonalities with other communication sector branches and to handle the technological postal system in more layers; similarly as the electronic communication systems are handled. Model of layer postal system, based not only on the processes but on layers functionality, will enable to identify communication protocols and interfaces determining interoperability. It also opens the question of appropriate regulation model.
\end{abstract}

Keywords: Layer, Process, Model, Postal System, Interconnection, Regulation

\section{Introduction}

Postal services continue to have a central role in the development of an effective and dynamic Single Market. However, the role of postal services is changing fundamentally. Demand for distribution of letters, newspapers, advertisements, and other documents is declining due to the rise of advanced electronic communications. At the same time, demand for parcel delivery services is increasing due to the development of e-commerce, and also just-in-time manufacturing. But the big threat is substitution by electronic services and other business trends driven by the new electronic technologies.

Designated postal operator shall ensure that users enjoy the right to a universal service involving the permanent provision of a postal service of specified quality at all points in their territory at affordable prices for all users. It must be allow all postal operators non-discriminatory access to elements of their postal infrastructure (as an address databases and post office boxes) when necessary to protect the interest of users or to promote effective competition. A lot of designated postal operators have not developed a consensus on how to implement this requirement. The requirement of non-discriminatory access is complicated in both legal and regulatory aspects (Švadlenka, Chlaň, 2009). It shows the complexity of technical and technological feasibility which is related with ensuring the interoperability of technological systems. The question that arises is the determination of access points in the network of an universal service provider and the establishment of conditions for access and connection to other postal operators. This requires the confrontation of processes for collection and distribution of packages with the construction of postal transmission network and it also requires a search of common intersections in the postal systems. This fact leads to the idea to examine the postal system not only from a procedural point of view, but also to look at 
it as an open communication system, what is typical for other departments of communication sector (transport, electronic communication) (Vaculík, Tengler, 2012).

\section{Current state and starting points}

Normative and regulatory aspect in defining and assessing of the postal services is often completed by an analysis of the entire postal chain consisting of four basic activities/processes that form the postal service (collection, sorting, transport, delivery) (Figure 1).

This kind of postal services is apparent also in the evaluation reports by European Commission (2010, 2013) or in the professional reports and discussions of many authors (Čorejová, Imríšková, 2008; Madleňáková, 2013). It is a view of the postal service to the analysis of processes and sub-processes taking place in the networks, which is particularly relevant in recent times in terms of addressing interoperability and control access to the public network.

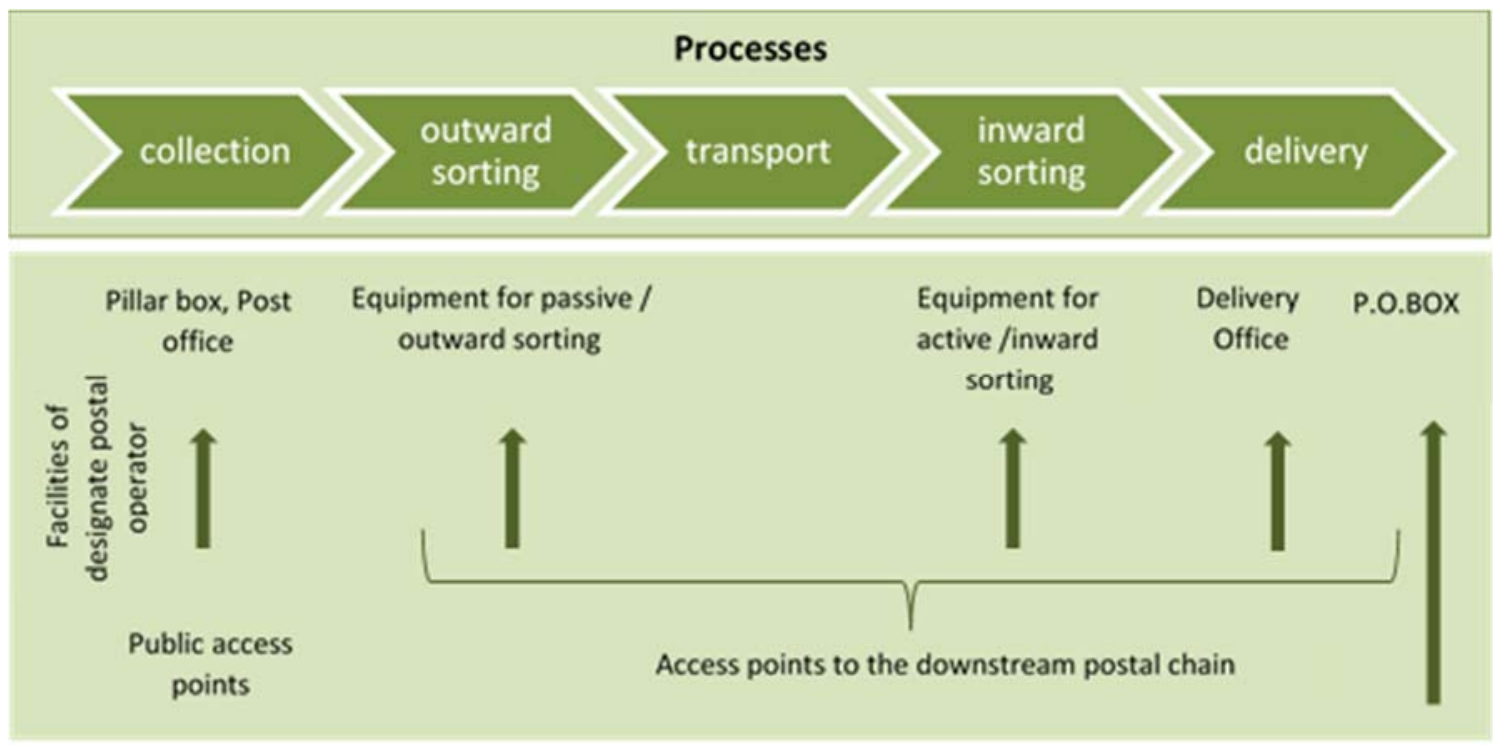

Figure 1. Postal chain and points for access to the public postal network

The network character of postal services is not different from other network systems. The overlapping of common features is apparent mainly in transport and communicational systems, whether we speak about construction and organization of networks or in the character and requirements for coverage of territory, mainly in the connection with regulated services of general public interest. Although we are accustomed to portrayal of postal services through the processes and sub-processes, it is possible to see the postal system at a certain level of abstraction also in layers as in the case of telecommunication services and transport systems. Agreement is significant especially in terms of the service provided through the model of layers, in which the basis consists of the physical layer, network layer, and layer of services. The physical layer represents a means of transport or vehicle of transport and it is responsible for the physical realisation of transmission in the case of telecommunication. The network layer expresses mainly the creation of interconnection for transport requirements or for the transfer of message in telecommunication.

\section{Layers of the postal systems}

The selection of package and its distribution can be describe between postal systems and the way of its connection on the basis of the model principles for communication of open systems. We will describe not only the immediate shipment of package between the systems, but also the abilities of the system to collaborate and to create the interconnected postal systems on the basis of grouping that consists of one or more access points, related hardware, terminals / hubs / depots, human features and vehicles used for the carriage of postal substrate, etc (Zeman, Madleňák, 2010).

In the postal system the communicating devices will be represented by the means of the "layer architecture". This layer architecture is characterized by the hierarchical organisation of the functions (entities) that are needful for linking system. The highest layer allows the contact with the user interface 
(e.g. with network subscribers) and the lowest layer allows the contact with the physical transmission medium. Different functions are allocated to the individual layers of model that enable the realisation of "the system interconnection" (Carvalho, Suri, Arguedas, Rebeschini, Breedy, 2007). The architecture of the open system is made up from number of subsystems - layers that are stored on each other. Every layer contains interface between the nearest higher and the nearest lower layer. The highest layer has the interface towards the user environment and the lowest layer towards the transmission medium.

\subsection{Characteristics of basic elements of postal layer model}

The model of opens system for communication defines a hierarchical architecture that logically partitions the functions required to support system-to-system communication. And the layered approach offers several advantages. By separating networking functions into logical smaller pieces, network problems can more easily be solved through a divide-and-conquer methodology (Table 1). The layers model also allows extensibility. New protocols, requirements and other network services are generally easier to add to a layered architecture (Madleňáková, Madleňák, 2014).

Table 1. Basic elements of the postal layer model

\begin{tabular}{|c|c|}
\hline $\begin{array}{l}\text { Element of the postal layer } \\
\text { model }\end{array}$ & Basic characteristics \\
\hline Layer & $\begin{array}{l}\text { - part of the network's function } \\
\text { - those functions depend on each other- one function provides its services to another while using } \\
\text { the services of other layers. } \\
\text { - It is important to note, that only the same layers (equal) of the postal system will communicate } \\
\text { between the sender and the addressee during the relocation process and transport of the } \\
\text { package }\end{array}$ \\
\hline Function / Functionality & $\begin{array}{l}\text { - constitute a certain functioning, security operation or determination of specific activities in the } \\
\text { transfer process. } \\
\text { - also determine the relationship between two layers. } \\
\text { - limits the layer competence, role and its importance in ensuring of goal achievement- the } \\
\text { transfer of the package from the sender to the recipient. }\end{array}$ \\
\hline Protocol & $\begin{array}{l}\text { - It may be characterised as a register, report, record of the process or a result of the activity or } \\
\text { operation, for example a book of records about the acceptance and dispatch of packages. On } \\
\text { the other hand, it may be a sum of the procedures and rules determining the operation of the } \\
\text { installation or method of communication between endpoints in the postal system. }\end{array}$ \\
\hline Interface & $\begin{array}{l}\text { - is defined as a border between two layers. It can be a set of elements that are necessary for the } \\
\text { connection of one device to another, for the purpose of ensuring communication or shipment } \\
\text { relocation. } \\
\text { - The interface in layer postal model is formed by a physical point (mailbox, post office box), } \\
\text { but it is formed also as a set of norms, regulations and protocols defining characteristics of a } \\
\text { connection that may be virtual/ electronic. }\end{array}$ \\
\hline Security & $\begin{array}{l}\text { - as a minimization of the "vulnerability" whether of the postal substrate that enters the } \\
\text { technological system or instruments and procedures that ensure the distribution of the postal } \\
\text { substrate. Security features provided in the architecture of open systems will be effective only } \\
\text { if they are used together with the safety instruments that belong also beyond the specified } \\
\text { architecture. }\end{array}$ \\
\hline Quality & $\begin{array}{l}\text { - as a degree of achievement of the customer's expectation with the provided service and as a } \\
\text { disproportion between expectations and perceptions. } \\
\text { - is determined by the normative requirements and its level is dependent not only on the } \\
\text { perception of impact- the output process, but mainly on the quality of the whole process. }\end{array}$ \\
\hline
\end{tabular}

\subsection{Basic characteristics of the layers formation in the postal system}

In the formation of the layer model (Madleňáková, Madleňák, 2014) that is applicable for postal systems, it is necessary to preserve the possibility of using different kinds of transport (physical media) with the different management practices (Table 2).

We can divide layers on the basis of their characteristics and functional content into two basic groups: either in terms of their functions within the network, or from the perspective of user access (Kolarovszki, Vaculík, 2014). Division of layers in terms of their functions within the network:

1. End-oriented layers- they are implemented only into the terminals (applicative, presentational, relational, transporting).

2. Network-oriented layers- they are dependent on the network technology that is used and they have to be at least partially implemented into the network (network, line, physical).

Division of layers in terms of their users: 
1. User-oriented layers (applicative, presentational, relational) - they play important roles in interpretation of the data to user.

2. Transport-oriented layers (transporting, network, line, physical) - they are related to the distribution of the package.

The transport layer can be described also as so called interlayer that forms an interface between useroriented layers and network-oriented layers. (La Red Martínez, Agostini, 2014)

Table 2. Basic characteristics of the layers formation in the postal system

\begin{tabular}{|c|c|}
\hline $\begin{array}{l}\text { Type of the layer in the } \\
\text { postal system }\end{array}$ & Basic \\
\hline $\begin{array}{l}\text { Application - layer number } \\
7\end{array}$ & $\begin{array}{l}\text { The application layer includes the postal service of which disclosure is required by the sender } \\
\text { through the entry of the postal system. }\end{array}$ \\
\hline $\begin{array}{l}\text { Presentation - layer } \\
\text { number } 6\end{array}$ & $\begin{array}{l}\text { The presentation layer transforms the package into the shape that is used by application. It } \\
\text { determines the conditions for the requested service and it sets rules for the choice and distribution } \\
\text { of packages. The protocols are based on legislative measurement. It deals with the formal aspect } \\
\text { of package (cover, address information) and with the preservation of information content during } \\
\text { the transport. Its task is to ensure the secrecy of correspondence. }\end{array}$ \\
\hline Session - layer number 5 & $\begin{array}{l}\text { The relational layer organizes and synchronizes dialog between co-relational layers of both } \\
\text { systems and it controls the exchange of data between them. It creates a connection between the } \\
\text { sender and the addressee through the application of defined protocols- the selection of suitable } \\
\text { cover for package and the presentation of personalized features, followed by submission of } \\
\text { package- the enter into the postal system. The mailbox or partition are considered to be the } \\
\text { interface. In the case of system's failure to deliver the package, it may be returned to the sender } \\
\text { on the basis of referred synchronized data- address (sender, recipient). }\end{array}$ \\
\hline Transport - layer number 4 & $\begin{array}{l}\text { The transport layer manages the transport of postal item from end node source (open system), } \\
\text { into targeted end node (open system) that is not realised in internodes. This layer reminds us an } \\
\text { illusion as if each node in the network had direct connections with any other node. It ensures the } \\
\text { creation of transport units from expedition of packages and their deconsolidation in delivery. Its } \\
\text { purpose is to provide such quality distribution that is required by higher layers. This required } \\
\text { quality is maintained throughout whole time of the transport connection. Higher layer is informed } \\
\text { in the case of quality failure (service T \& T). This includes for example the application of } \\
\text { protocols related to the requirements for distribution with guarantee (recorded packages as } \\
\text { registered mail, insurance ...) and the requirements for distribution without guarantee (non- } \\
\text { registered mail). The guarantee can be applied also to loss and damage of the package. }\end{array}$ \\
\hline Network - layer number 3 & $\begin{array}{l}\text { The network layer takes care about the direction of packages within the network and network } \\
\text { addressing. It provides the connection between the systems that are not neighbouring ones. It } \\
\text { means, that some systems have a function of an end source (post) and a goal of dispatched } \\
\text { package (the delivery post office, PO Box...) and vice versa. Some open systems have functions } \\
\text { of internode link (processing centres) that ensures the handover of distributed postal substrate to } \\
\text { another systems. The basic function of this layer is a collection of network-oriented protocols for } \\
\text { the goal of correct shipment (sorting feature, e.g. Zip code) and crossing of different technological } \\
\text { characteristics that are applied in individual networks. This layer provides a connecting path } \\
\text { between endpoints (the sender and the addressee), including the use of internodes. It is } \\
\text { responsible for the selection of the best path between the terminal equipment and transport } \\
\text { between them, as well as the delivery. }\end{array}$ \\
\hline Line - layer number 2 & $\begin{array}{l}\text { The line (data link) layer provides a connection between two neighbouring systems, respectively } \\
\text { nodes. It identifies and organizes packages from the physical layer into logical units and it } \\
\text { provides the connection of neighbouring nodes and enables the setting of transmission data } \\
\text { between two nodes. Its function is also to ensure the formation of transport units on the basis of } \\
\text { codes such as: (ZIP, ZIP code, label of direction...), and it announces the errors of sorting and } \\
\text { loading. Its task is to ensure the functions in transport of postal substrate between the network } \\
\text { units and the detection of errors that occur in physical layer. }\end{array}$ \\
\hline Physical - layer number 1 & $\begin{array}{l}\text { The physical layer (the lowest layer of architecture) is identified as a physical communication } \\
\text { (shipment) in available infrastructure (road, rail, air, water), that is provided through physical } \\
\text { media (a means of transport). This layer specifies the characteristics of individual vehicles (postal } \\
\text { rates), such as capacity, loading surface and it also defines the way of shipment. Another devices } \\
\text { that belong into this layer are different types of nodes for example (depots, hubs ...). }\end{array}$ \\
\hline
\end{tabular}

\section{Case study - Basic conception of layer postal system model}

During application of the layer model into environment of the postal system, it is possible to think about the integration of chosen layers. This is possible just in the case of insufficiency of functional filler, or in the functional intersection of the individual layers, in which the interface identification between layers or setting of communicating protocols will be not possible. (Madleňáková, 2013).

One option is the creation of a model that works in three layers, established on the basis of their functionality, in which the theory of network systems works with them on the basis of ISO/OSI recommendations. User-oriented part of the layer model is the same as in the previous case, it is more 
oriented on the field of determining the commercial-marketing parameters and defining of the relationship: user-provider. Modelling of other parts is based on the assumption that an important part of the model, that contains clear rules regarding the determination of technological processing of the package (the type of the service is important), is a transport layer. This is the reason why, its function is irreplaceable in the model, and it is not appropriate to combine it with lower network-oriented layers that are equally important.

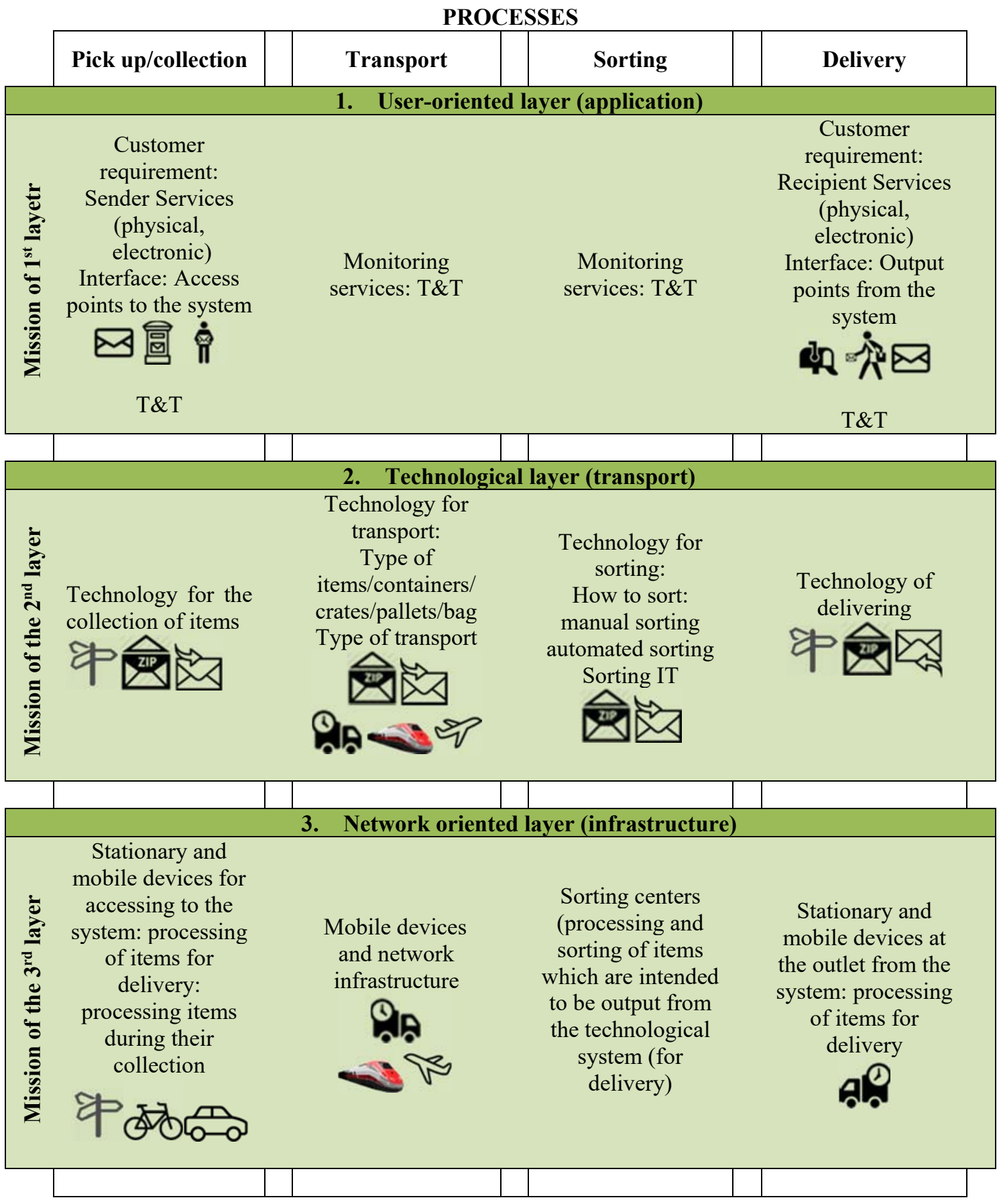

Figure 2. Missions and processes of the layer oriented model

The Figure 2 shows that by use of sufficient disaggregation, the postal market can be analysed both along processes as well as along layers. The result is the same in both approaches. The layers show the access points to the postal system, methods of communication and management. Penetration of ICT services (in the form of supplementary services) in the postal sector in the layered system allows better control and set regulatory rules for both areas (postal and telecommunications) (Heitzler, 2009). 
Table 3. This is an example of a Table

\begin{tabular}{|c|c|c|}
\hline \multirow{5}{*}{ 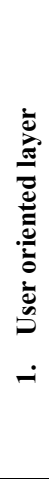 } & Basic function & $\begin{array}{l}\text { - } \quad \text { the creation of consignments to the required service } \\
\text { activities and related processes along the way from the sender to the postal system / } \\
\text { postal provider (mailbox, post office box, courier ...) and pick up, collection } \\
\text { - customer contact with the postal provider and access to the postal system. }\end{array}$ \\
\hline & Protocol & 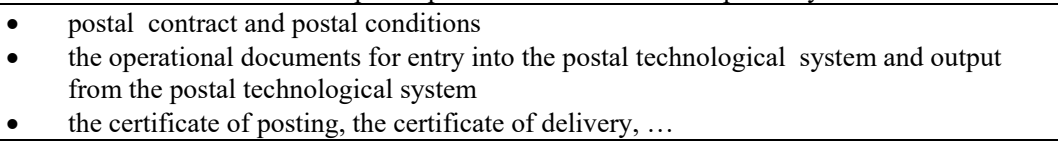 \\
\hline & Interface & - $\quad$ post office, mailbox, courier, hub, ... \\
\hline & Quality & $\begin{array}{l}\text { - } \\
\text { - } \\
\text { - } \\
\text { - } \\
\text { on time accessibility of the access and contact points of the postal network } \\
\text { security of the items and information on the postal service }\end{array}$ \\
\hline & Security & - $\quad$ postal secrecy \\
\hline \multirow{6}{*}{ 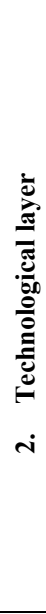 } & Basic function & $\begin{array}{l}\text { - } \quad \text { way of processing shipments and choice of technological processes } \\
\text { - } \quad \text { routing shipments and way of consolidation and deconsolidation of shipments }\end{array}$ \\
\hline & $\begin{array}{l}\text { Service provided for } \\
\text { user-oriented layer }\end{array}$ & $\begin{array}{l}\text { - } \quad \text { identification of points on the network using directional address } \\
\text { - } \quad \text { mapping application for the distribution of postal substrate (shipment, container, ...) }\end{array}$ \\
\hline & Protocol & $\begin{array}{l}\text { - traffic rules - determine the method of processing shipments, monitoring consignments } \\
\text { and rules for delivery of the shipment. }\end{array}$ \\
\hline & Interface & $\begin{array}{l}\text { - border with user-oriented layer is given access point (mailbox, post office counter, } \\
\text { courier, PO Box ...). }\end{array}$ \\
\hline & Quality & $\begin{array}{l}\text { - level in relation to the requirements of the user layer } \\
\text { - } \quad \text { it depends on the quality of the network layer } \\
\text { maintained during the whole period of the distribution process. } \\
\text { - } \quad \text { information on non-compliance with quality standards for user-oriented layer }\end{array}$ \\
\hline & Security & $\begin{array}{l}\text { Security services and their combinations: } \\
\text { - } \quad \text { identification of the postal substrate (postal items, transport unit) } \\
\text { the source site (endpoints, pick up points, points of processing) } \\
\text { - } \quad \text { management of the postal substrate processing (routing of consignments) } \\
\text { integrity of the distributed postal substrate (postal secrecy and integrity of postal items, } \\
\text { consignment, transport unit) }\end{array}$ \\
\hline \multirow{6}{*}{ 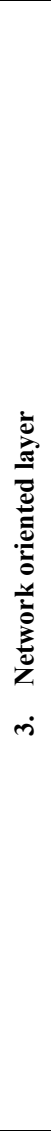 } & Basic function & $\begin{array}{l}\text { - utilization of available infrastructure and the relevant type of transport to ensure the } \\
\text { transport of postal substrate by the operational postal courses/line haul } \\
\text { create topological links between existing network nodes, creating a connection of two } \\
\text { neighboring nodes } \\
\text { - } \quad \text { addressing, routing and tracing cargo / transport units to their destination. }\end{array}$ \\
\hline & $\begin{array}{l}\text { Service provided for } \\
\text { technological layer }\end{array}$ & $\begin{array}{l}\text { - transport of postal substrate in the prescribed form by the selected network path, } \\
\text { - } \quad \text { addressing network based on the identification elements (identifier) } \\
\text { making network connections from point to point, } \\
\text { - } \quad \text { ensuring quality of service and local error detection. }\end{array}$ \\
\hline & Protocol & $\begin{array}{l}\text { network address - directional character that uniquely identifies each of the end systems } \\
\text { (to ensure access to the subnet, or the network of other postal system) } \\
\text { rules for the management of flows between nodes (transport order, postal traffic plan, } \\
\text { timetable ...) } \\
\text { administration and management of the physical connection (postal traffic plan, transport } \\
\text { schedules, timetables ...) }\end{array}$ \\
\hline & Interface & $\begin{array}{ll}\text { - } & \text { node in the network } \\
\text { - } & \text { place for transshipment traffic units (shipments, containers) / loading ramp } \\
\end{array}$ \\
\hline & Quality & $\begin{array}{l}\text { quality depends on the agreement between the technological infrastructure services layer } \\
\text { and the layer when selecting the network path (end point will be the same as declared at } \\
\text { the beginning), derived from used topological connected nodes to the network and the } \\
\text { means of transport } \\
\text { ensure the performance parameters, such as: availability, reliability, network bandwidth } \\
\text { speed - transportation time (a failure), network error, error associated with the wrong } \\
\text { delivery, and will like }\end{array}$ \\
\hline & Security & $\begin{array}{l}\text { - } \\
\text { - } \\
\text { access to the subnet or network. } \\
\text { security protection is always carried out before the enforcement of the common features } \\
\text { pre-shipment in the stream and the normal functions of film - after acceptance of } \\
\text { delivery by the next node (confidentiality relocation). } \\
\text { to protect the entire flow of shipments and implementation of confidentiality flows and } \\
\text { connections between nodes. In particular: } \\
\text { o identification of the location of the mail substrate / shipment } \\
\text { o secret connection between nodes (end) } \\
\text { o confidentiality transported flows and integrity relocation. }\end{array}$ \\
\hline
\end{tabular}




\section{Conclusions}

Layer model offers an alternative view of a mail system in which different phases of the distribution process can describe by the layers instead of process. The task of the layers is to ensure the obligation to use a particular type of technology or equipment, to provide guidance where necessary to ensure consistency in communication and set the rules for the interconnection of networks. The determination of the individual layers functionality contributes to the identification of several facts that can serve as an innovative element for the future arrangement of postal networks (Table 3).

Functions, tasks and rules for communication between different postal systems in the infrastructure part of the model point to the possibilities of ensuring a transparent access to the incumbent's (operator's) postal network and interoperability between postal systems. The aim of the interoperability between postal systems is to build a monolithic block of services of the sub components for users. These components are technically different and managed by different operators. For interoperability, it is necessary to consider three essential aspects: organization of the system, hierarchy, the legislative environment and applied standards. The organization of the system is given by organizational interoperability. It consists in defining the aims of modelling business processes and collaboration postal subjects. Organizational interoperability can be achieved by identifying and determining the interface (eg. access points), declaring the technical requirements to ensure the functional interconnection of postal systems and services.

\section{Acknowledgements}

VEGA 1/0721/15 Research on the impact of postal services and telecommunication convergence on regulatory approaches in the postal sector.

\section{References}

1. Ahuja, R.K., Magnanti, T.L., Orlin, J.B. (1993) Network Flows: Theory, Algorithms, and Applications. Prentice Hall, New Jersey, ISBN 978-0-136-17549-0.

2. Boldron, F., Cremer, H., De Donder, P., Joram, D., Roy, B. (2009) Network externalities and the USO: a two-sided market approach. Article in book: Progress in the competitive agenda in the postal and delivery sector. Elgar, p. 184-195, ISBN 978-1-8484-4060-9.

3. Carvalho, M., Suri, N., Arguedas, M., Rebeschini, M., Breedy, M. (2007) A cross-layer communications framework for tactical environments, In: Proceedings - IEEE Military Communications Conference MILCOM, art. no. 4086619, DOI:10.1109/MILCOM.2006.302357

4. Čorejová, T. and collective (2010) Economics of networks. Second Edition. Žilina: University of Žilina - EDIS, - 322 p., ISBN 978-80-554-0155-3

5. Čorejová, T., Imríšková, E. (2008) Integracja na rynku usług pocztowych (Convergence at the postal market). Eksploatacja i Niezawodność. Volume 39, Issue 3, 2008, p 74-76 ISSN 1507-2711

6. Čorejová, T., Rostášová, M., Chrenková, A., Madudová, E. (2013) Regional dimensions of knowledge processes in the sector of transport and logistics and ICT in the Žilina region In: Communications: scientific letters of the University of Žilina. Volume 15, No. 2, p. 25-33. - ISSN 1335-4205

7. Heitzler, S. (2009) "Traditional Regulatory Approaches and the Postal Service Market", Competition and Regulation in Network Industries. In: Econ Papers. Volume 10, Issue 1, pages 77-106.

8. Hrudkay, K., Šestáková, S. (2014) Systémy riadenia terminálov intermodálnej prepravy. In: vedeckoodborný seminár ,, Výskumné aktivity v doprave, stavitel'stve a príbuzných odboroch “, Herl'any, 21.22. január 2014. Herl'any: Slovenská spoločnost' logistiky, ISBN 978-80-971604-6-3

9. Knieps, G, Zenhäusern, P., and Jaag, C. (2009) Wettbewerb und Universaldienst in europäischen Postmärkten, In: Fallstudien zur Netzökonomie, Wiesbaden: Gabler, 87-110

10. Kolarovszki, P., Vaculík, J. (2014) Middleware - Software support in items identification by using the UHF RFID technology In: Lecture Notes of the Institute for Computer Sciences, Social-Informatics and Telecommunications Engineering, LNICST, 131, pp. 358-369. DOI: 10.1007/978-3-319-115696_28

11. Luo, W., Han, P., Gao, F. (2009) Study on System Modeling and Analyzing of Supply Chain Network, In: IEEE International Conference On Automation And Logistics (ICAL 2009), Vols: 1-3, pp. 15981602, ISBN: 978-1-4244-4794-7

12. Madleňák, R., Madleňáková, L., Dydňanský, P. (2013). Global postal network - a trade facilitator for the small and medium enterprises for entering the global market. International Journal of Arts and Commerce. Vol. 2, No. 5, p.109-114. ISSN 1929-7106. 
13. Madleňáková, L. (2013). Layer model of the postal system. Habilitation Thesis - University of Žilina, Faculty of Operation and Economics of Transport and Communications. Žilina: 112 pages.

14. Madleňáková, L., Madleňák, R. (2014) Layer model of the postal system In: Reliability and statistics in transportation and communication (RelStat'14), Riga, Latvia, October 2014. Riga: Transport and Telecommunication Institute, p 106-113 ISBN 978-9984-818-70-2.

15. Maegli, M., Jaag, Ch., Koller, M., Trinkner, U. (2010) Postal Markets and Electronic Substitution: What is the Impact of Convergence on Regulatory Practices and Institutions? In: ECPR conference: 'Regulation in the Age of Crisis', Dublin

16. La Red Martínez, D.L., Agostini, F. (2014) ISO/OSI model and data communication by animations, In: WIT Transactions on Information and Communication Technologies, 58 VOL I, pp. 963-970, DOI: 10.2495/ICTE131162

17. Pastor, O., Tuzar, A. (2007) Theory of transport systems, ASPI Praha, ISBN 978-80-7357-285-3

18. Sutanto, S., Heller, R. (1993) Utility Communications Architecture Review, In: ISA Transactions, Volume: 32, Issue: 3, pp. 297-300, DOI: 10.1016/0019-0578(93)90029-V, ISSN: 00190578

19. Švadlenka, L., Chlaň, A. (2009) Principles of the Proposed Czech Postal Sector Price Control Model. PROMET Traffic \& Transportation. Scientific Journal on Traffic and Transportation Research. Sveučilište u Zagrebu, Fakultet prometnih znanosti, Zagreb, Croatia. No. 1, Vol. 21, p. 33-40. ISSN $0353 / 5320$

20. Vaculík, J., Tengler, J. (2012) Potential of new technologies in logistics services, In: Congress Proceedings - CLC 2012: Carpathian Logistics Congress, pp. 242-250.

21. Zeman, D., Madleňák, R. (2010) Application of the OSI reference model in terms of the design creation of postal transportation networks. In: Perner's Contacts. ISSN 1801-674X. Volume 5, č. 3, s. 422-429.

22. ITA Consulting \& WIK-Consult (2009) The Evolution of the European Postal Market since 1997 